\title{
Debating (Post-)Coloniality in Southeast Europe: A Minority Oriented Perspective in Bulgaria
}

\section{FRANCESCO TRUPIA ${ }^{1}$}

\begin{abstract}
Despite the fact that its scholarly application has been considered highly problematic in the former Eastern Bloc and barely employed due to the Marxist background, post-colonialism has been recently introduced by a large number of scholars and academics. Yet, theoretical experiments, research, and projection of post-colonialism in Central and Eastern Europe have come to compose an abundant field of reference. Drawing on this theoretical approach, this paper aims to debate the category of post-coloniality in postcommunist Bulgaria in order to better venture the parapet of the post-1989 transition. Employing a 'minority perspective, which will reveal minority positionality in the contemporary Bulgarian cultural and political ground, this paper traces potential power actions of (dis)possession of knowledge among subaltern groups, which actions continue to negate, disavow, distort, and deny access to different forms of minority cultures and life visions represented by non-majoritarian segments of the Bulgarian society. In general, this paper digs into the historical experience of the ethnic Turks and Muslim minority groups in Bulgaria prior to (1) the communist experience, (2) throughout and after the collapse of communism, and (3) in the contemporary Republic of Bulgaria. In particular, post-coloniality - understood in terms of 'coloniality of being' - shall offer a better and critical angle of investigation over the issues of human marginalisation, cultural subordination, and knowledge exploitation in Bulgaria and Southeast Europe.
\end{abstract}

Keywords: post-coloniality, Bulgaria, post-1989, ethnic Turks, Muslim minority

\section{Introduction}

In the constant attempt to investigate new intersectional aspects of postcommunist Central and Eastern Europe, the post-colonial transfer ${ }^{2}$ gained

1 Francesco Trupia, Postdoctoral Scholar, Centre of Excellence Interacting Minds, Societies and Environments (IMSErt), Nicolaus Copernicus University, e-mail: trupia.francesco90@gmail.com

2 Dorota Kołodziejczyk, 'Post-Colonial Transfer to Central-and-Eastern Europe', Teksty Drugie no 1 (2014) (Special Issue), 124-142. 
popularity among scholars. Whether or not a post-colonial $\mathrm{CEE}^{3}$ has arguably existed, or continues perhaps to exist, has become a fascinating interdisciplinary inquiry long before 1989 .

However, thirty years after the demise of the formerly so-called Eastern Bloc, the post-colonial paradigm remains largely controversial and contested across the region. Since the paradigm is deeply rooted in historical experiences of nations of the Global South and scholarly dependent largely on Marxist literature, ${ }^{4}$ the notion 'post-colonial' has been rejected or barely used in the post-communist academia. Nonetheless, experiments, research and projection of the post-colonial paradigm compose an abundant field of reference despite resonating negatively with the past of the region. Recent revival of ethno-national discourse and sense of collective anxiety towards the ethnic Other, the field of post-colonial studies and post-structuralism have not managed to cohabit with the anti-communist environment, while, conversely, civil society actors and resistant movements born before and throughout the postcommunist transition have largely employed it.

From a minority perspective, the post-colonial paradigm seems useful to venture the parapet of externally imposed discourse, which continues to dispossess, discard and set aside "Other's knowledge" through a power-organised, albeit subtle and lasting operation of cultural patronisation. In this, the post-communist and the post-colonial trajectories share vacuumed political programmes of inclusion that contrive intervals between which divisions and separations remain at the disposal of political entrepreneurs and their interests-oriented commitments. Arguably, it would seem that post-colonialism and its scholars, such as Gayatri Chakravorty Spivak, Edward Said, and Homi K. Bhabha, among others, have little to offer across the postCommunist space. Application of the post-colonial paradigm over the successor republics of the Soviet Union and formerly satellite region cannot reveal a 'Soviet colonialisation', but only a 'second class empire' that differs from those resulting from Western experiences. ${ }^{5}$ By the same token, a post-colonial paradigm seems to bring in the post-communist CEE more problems than benefits. ${ }^{6}$ On the contrary, one might argue that a post-colonial analysis in CEE missed the chance to include those minority resistances that between the '70s and the ' 90 s began to mobilise themselves through an anti-imperialist discourse. ${ }^{7}$ Despite the fact that the 'Soviets' are not understood as 'colonisers' in toto, the lingering problems of racism and ideological prison-style Nation's 'Proletarian superiority' over all other classes and segments of societies were blatantly colonial in its hierarchic methods of doing politics. The Party-state

3 From now on, CEE is used to abbreviate 'Central and Eastern Europe'.

4 J Peter Braueunlein, 'Postcolonial Theory', in Religion and Southeast Asia: An Encyclopaedia of Faiths and Cultures, ed. by Jesudas Athyal (Santa Barbara: ABC-CLIO, 2014), 1-8.

5 Madina Tlostanova, 'Towards a Decolonization of Thinking and Knowledge: a Few Reflections from the World of Imperial Difference', Decolonial Theory and Practice in Southeast Europe no 3 (2019) (Special Issue), 1-15.

6 Kołodziejczyk, 'Post-Colonial Transfer', 125-140.

7 Ibid. 133-134. 
rhetoric and its overwhelming propaganda machine, which trumpeted the virtues of egalitarianism and internationalism, was only later unveiled due to the demise of the former Eastern bloc. The latter meant nothing more than the failure of the Russian messianism, whose expansionism embodied for decades an imperial fatigue nurtured by orthodox outlook of religion, constructed around the dictatorship of the 'Great Proletariat' and developed by the Russians as the only constitutive ruling ethnos. ${ }^{8}$

Perhaps not entirely colonised, yet CEE could be understood as a historically semi-colonial region, ${ }^{9}$ where the relation to power was as ambiguous as the relation with the subaltern Other, the foreigner, the alien. ${ }^{10}$ Granted, both Russian and Western cultures were a discursively hegemonic reflection throughout diverse societies, upon which stereotypes of inferiority as well as otherness and subalternity were ascribed. Beyond a doubt, the aftermath of the communist demise was a clear manifestation of a wide range of one's own subjectivity (that is, collective, national, political) previously negated by an imperial discourse. Similarly to post-colonial states in the Global South, ${ }^{11}$ while post-communist successor states emerged with a mass of communities historically antagonistic and confrontational toward each other, others were found nurturing their new forms of antagonism to construe, or to construct, and nourish by a long-term period of colonially 'divide and imperial' policies.

The post-1989 transition toward full-fledged democracy opened anew the historical experience of cultural patronisation and power-centred oppression of non-aligned segments of society against those who had suffered the same period of oppression. Through externally imposed ascriptions of exotic downgrading and assertion of forms of cultural backwardness, a sharper correlation between the 'postcommunist' and 'post-colonial' can be conceptualised regarding minority identities (that is, hybridity, in-between-ness, and liminality). If the typically identifiable (post-) colonial states across the globe adopted majoritarian identities as national identities, dismissing Other's into another (subaltern) position to be accommodated, moderated, challenged, or even eliminated because seen and understood as a potential threat, ${ }^{12}$ the same phenomenon happened to the post-Communist states in CEE. In this regard, the post-colonial paradigm is neither an identity manifesto, nor a theoretically redefined identity policy program, nor the end of the colonial but its troubling continuity ${ }^{13}$ that shed new light on imposed discursive hegemonic ascriptions upon those who have been deprived to speak as independently, fully recognised subjects. Although

8 Ostap Kushnir, Ukraine and Russian Neo-Imperialism. The Divergent Break (Lanham: Lexington Books, 2018), 25-65.

9 Braueunlein, 'Postcolonial Theory'.

10 Ibid.

11 Joshua Castellino, "Identity and Human Rights in a "Populist" Era: Urging Caution and Pragmatism in Minority Rights Protection', in Populism, Memory, and Minority Rights. Central and Eastern European Issues in Global Perspective, ed. by Anna-Mária Bíró (Leiden: Brill, 2018), 342-356.

12 Ibid. 345-346.

13 Marianne Hirsch, The Postmemory Generation. Writing and Visual Culture After the Holocaust (New York: Columbia University Press, 2012), 5. 
navigating within post-communist societies through the prism of post-colonialism may be debatable, the latter may nevertheless lead towards a critical, analytical instrument to unravel identity issues digging up mechanisms of subordination that certain groups are subject to, navigating, thus revealing, nodal points and structures around and in-between which cultural backwardness and political subalternity have been imposed on.

Given this token, in this paper I argue that a form of factual colonisation could be conceptualised in CEE and, in its turn, in Bulgaria, with reference to post1989 majority-minority relations. From a historical viewpoint, a factual (post-) colonial phenomenon ${ }^{14}$ is nothing but a socio-cultural Bulgarian attitude of cultural patronisation which was simply reversed against those who once used it against them..$^{15}$ The paradigm of post-coloniality might raise criticism for not being properly employed and examined in a particular field or in those disciplines that secure its frontiers and contents. However, as a scholarly paradigm of discontinuity, postcolonialism is here used to put into question not only the procedure of its use, but also theoretical problems of historical analysis. ${ }^{16}$ Therefore, this paper aims to shed light on Bulgaria's factual colonialising attitude toward non-Bulgarian segments of society, which has been constantly power-organised through mechanisms of cultural patronisation against Other's being. This does not only reveal post-1989 trajectory of power where minority groups have fallen from a voiceless position to being considered claimers of frivolous and superfluous demands, but it is traced back to the first experiences of liberated Bulgaria from the 'Turkish yoke' in 1878. In few words, the paradigmatic vector brings light to the modalities of hegemonic appropriation and externally imposed ascription of cultural features that in Bulgaria have been kept at work in order to cement power position in certain segments of society rather than initiating a mutual process of empowerment upon 'other' cultures and groups. What is here considered as a much subtler category of thinking, which has been left working in the region and shaped a form of (post-)colonialising attitude, came in support of ethno-national majoritarian cultural models and subjugated minority cultural claims accordingly.

\section{A factual colonialisation? A minority perspective in Bulgaria}

Unlike other Balkan countries, Bulgaria did not apparently suffer from minority issues in the aftermath of communism. Paradoxically, albeit unsurprisingly during the communist period, Bulgaria declared to have no minorities in the country. ${ }^{17}$ Only during the period throughout the accession process to the European Union minority

14 Andrei Terian, 'Is there an East-Central European Post-Colonialism? Towards a Unified Theory of (Inter)Literacy Dependency', World Literature Studies 3, no 4 (2012), 21-36.

15 Michel Foucault, Nietzsche, Genealogy and History (Oxford: Blackwell, 1971), 157.

16 Michel Foucault, The Archaeology of Knowledge (New York: Routledge Classics, 2002), 23.

17 JF Brown, Bulgaria under Communist Rule (London: Pall Mall Press, 1970). 
issues appeared in the political discourse and the wider public. While attempting to guarantee internal stability to democratic institutions along with respect of the rule of law, human rights and minority rights ${ }^{18}$ Bulgaria had to fully assert the presence of non-Bulgarian citizens in its society. This presupposed a quite delicate manoeuvre that could not have taken the risk to impinge on post-communist Bulgaria's historical attempts to assert a 'Europeanised identity' which was historically denied to the country by the Ottoman Empire and the communist takeover. This newly proposed Bulgarian European identity went rapidly under research about political changes and relatedly different locations of space rather than consequences of power. From a geopolitical viewpoint, the post- 1989 period brought Bulgarians to definitely refuse a certain Oriental legacy that had prevented Bulgaria to return to Europe much earlier. Henceforth, socio-cultural and political microhistories of ethnic minority groups become centrally paramount for shedding light on how Bulgarian policies have kept ethno-nationalist signs of pathological revenge at work against non-Bulgarians. Along the Ottoman/post-Ottoman and communist/post-communist thresholds, it would be unwise to understand a power-centred Bulgarian cultural attitude and political approach toward minority groups in terms of factual colonialisation.

Some might here argue that the Bulgarian scenario with regard to the Muslim minority - the majority of whom are of Turkish and Roma origin - opens the view to a bigger picture regarding the cultural challenge to include European Muslims into a contemporary vision of Europe. ${ }^{19}$ Nevertheless, in Bulgaria and other Balkan countries likewise, the 'Europeanising project' has constantly separated the Balkan Muslims from the rest of the ethnic majoritarian cultural systems and, at the same time, from the rest of the Muslim world. ${ }^{20}$ On a cultural level, a full recognition of European Muslims as autochthonous peoples of Europe evokes in Southeast Europe the image of periphery. Particularly in Bulgaria, the political debate simply overlooks the presence, or discards the existence, of non-Bulgarian communities living in their national territory, namely in their historical land of origin.

Therefore, the proposed post-colonial paradigm might not only be a vector to scholarly investigate Southeast Europe since the victory of the First World War by the great powers of the twentieth century exposed and broke down the same region along the axially artificial barrier of South-North and West-East Europe ${ }^{21}$ It might also delineate a colonisation-like political attitude toward Muslims in Bulgaria as

18 Spasimir Domaradzki, 'Opportunistic Legitimisation and de-Europeanisation as a Reverse Effect of Europeanisation', Global Discourse. An Interdisciplinary Journal of Current Affairs 9, no 1 (2019), 223.

19 Gerald Shenk, 'What Went Right: Two Best Cases of Islam in Europe - Cordoba, Spain and Sarajevo, Bosnia', Occasional Papers on Religion in Eastern Europe 26, no 4 (2006), 7-20.

20 Piro Rexhepi, 'Unmapping Islam in Eastern Europe: Periodization and Muslim Subjectivities in the Balkans', in Eastern Europe Unmapped: Beyond Borders and Peripheries, ed. by I Kacandes and Y Komska (New York: Berghahn, 2018), 53-78.

21 Timothy Snyder and Katherine Younger (eds.), The Balkans as Europe, 1821-1914 (Rochester: University of Rochester Press, 2018), 2. 
a consequence of the Soviet new-style colonies across the Eastern Bloc that suppressed national inspirations, ${ }^{22}$ and the more locally-nuanced factual colonisation of central power toward ethnic minorities within each People's Republic. Not surprisingly, during the event held in Sofia in 1966, the communist Romania's leader Ceaușescu addressed his Bulgarian alter ego Todor Zhivkov by remarking how Balkan people, who had historically been quite often the pawns of the imperialist powers in their policy of domination and conquest, had a mutual interest in cooperation. If the politicsoriented interests by which that speech was delivered are clear, addressing directly Zhivkov and his position on Bulgaria's favourable relations with USSR, it seemed that the idea of Soviet imperialism was haunting across Southeast Europe, notably in Yugoslavia with the Non Alignment Movement (NAM). Both post-communist Romania and Bulgaria's transitions toward fully-fledged democracy occurred with an overwhelming ethno-nationalist sentiment and anti-communist rhetoric which reinforced a centralist character of the national state. As a matter of fact, societal position of national minorities rapidly deteriorated. ${ }^{23}$

However, Bulgaria's factual colonisation toward non-Bulgarian people began much earlier than the communist takeover. In fact, the simply reversed historical process of cultural colonisation against those who once used the same method against Bulgarians, namely the Ottoman Turks, began to take place against the nonanymore hegemonic Turkish minority even before the liberation of the country in 1878. For instance, in contemporary Southern Bulgaria, formerly Eastern Rumelia, ethnic Turks - almost all of whom were Muslims - began to experience the attacks of Christian Bulgarians since 1876. Similarly, in the Northern region, Muslim centres and buildings such as the large library of old Turkish books and the mosque in Tûrnovo were destroyed in 1877. In Sofia, the 'forest of minarets' was definitely cut down in December 1878. The liberation from the Ottoman rule put some pressure on Muslims, who forcedly remained marginalised in rural areas they had historically inhabited. Although the Treaty of Berlin (1878) emphasised the rights of property to Muslims in Eastern Rumelia, insisting upon freedom of worship for all faiths and outlawed discrimination on the basis of religion, Bulgaria respected only on paper such indications. ${ }^{24}$ In fact, a period of disorientation and psychological demoralisation among the Turkish population followed several forms of oppression: villages were burned and locals driven from their lands. Turks and Pomaks who decided to remain in Bulgaria rather than emigrating toward Turkey, kept a traditional lifestyle without changing social habits and separating themselves from ethnic Bulgarians who began to consider 'old-fashioned' their lifestyle. In addition, subtler forms of oppression

22 James Mark et al., 1989. A Global History of Eastern Europe (Cambridge: Cambridge University Press, 2019), 177.

23 François Fejtö, A History of the People's Democracies. Eastern Europe Since Stalin (Middlesex: Penguin Books, 1974), 247-414.

24 R Julian Crampton, A Concise History of Bulgaria (Cambridge: Cambridge University Press, 2005), 112-113. 
were carried out. For instance, since Turks were accustomed to leave part of their land fallow, Bulgarian authorities interpreted such agricultural practice as a 'Turkish forfeit' of properties, thereby considering their lands terrae nullius to own. Moreover, taxes on land hit Muslim landowners ${ }^{25}$ who were not excluded to serve the Bulgarian Army. Although they were not obliged to wear Christian symbols on their uniforms, yet they were forced to obey Christian officers, observe Christian festivals and eat Christian food. Measured by mother-tongue, the number of ethnic Turks declined rapidly, ${ }^{26}$ and in September 1940 in Southern Dobruja many 'Ottoman name places' were changed. ${ }^{27}$

Once the Communist ruling elites cemented their power position, attempts to awake a 'socialist consciousness' among the Turkish and Muslim minority ${ }^{28}$ were carried out accordingly. A kind of Bulgarian psychological revenge against the 'Ottoman Turks' was kept at work, politically veiled by the fact that Islam would have played a dangerous role in a communist society due to its cultural and religious distinctiveness. Islam was indeed perceived as an obstacle for the progress of the communist society despite the fact it was barely performed..$^{29}$

Throughout the communist experience, Bulgaria continued to face some troubles with the same Turkish minority members (750,000, or 10 per cent of the population) due to their refusal to be ideologically assimilated. The majority of ethnic Turks were not essentially disturbed by the anti-Turkic campaign, such as the one conducted by Rabotnichesko Delo, the official voice of the Bulgarian communist regime, which constantly targeted Islam and Turkey as perilous entities for the country. However, rather than a religious concern, Islam was externally presented in Bulgaria as a leading-threat instrument against the communist state in order to hide the real political purposes and real power concerns. ${ }^{30}$ The homogenously and geographically compact mass-disagreement of the Turkish peasantry against communist institutions began to be expressed in forms of resistance against land collectivisation.

Interestingly enough, it must be pointed out that such 'Turkish peasantry resistance' was kept voiceless and depoliticised by communist Bulgaria's machinery of propaganda as well as by the minority's attitude to remain immune from it while renouncing to understand Turkey as their country of origin. Because of this, ethnic Turks and Muslims could not catch the momentum when many oppositionists in the 1970s were discovering the importance of political and civic freedoms, beginning to constitute the liberal consensus for the post-1989 transition to democracy. In fact, while across the Eastern Bloc anti-party mobilisation was inspired by anti-imperialist

25 Ibid. 112.

26 Ibid. 113.

27 Ibid. 204.

28 Ina Merdjanova, 'Uneasy Tolerance: Interreligious Relations in Bulgaria after the Fall of Communism, Occasional Papers on Religion in Eastern Europe 26, no 1 (2006), 1-11.

29 Crampton, A Concise History, 58.

30 Fejtö, A History, 295. 
solidarities and anti-colonial movements, ${ }^{31}$ Bulgaria's Turkish peasantry did not manage to defend their socio-economic rights as well as basic civic-political rights. Moreover, they missed the chance to employ a vocabulary of anti-imperialist selfdetermination that was commonly used by minorities in multi-ethnic States ${ }^{32}$ and by trade unions' independent resistances such as Solidarność in Poland.

Particularly in socialist countries with substantial Muslim minorities, such as in Yugoslavia and the Soviet Caucasus, Muslims experienced intermittent persecution since 1956. In Bulgaria, campaigns of oppression and cultural patronisation were carried out without interruptions instead. In 1951, 154,000 ethnic Turks from Southern Dobroudja were 'repatriated' in Turkey, even though Ankara expressed its unwillingness to absorb them by shutting its gates along one of the most debated borders of the Eastern Bloc. During communism, fewer than 1 per cent of Muslims attended and graduated from Bulgarian universities due to a large exclusion from higher education and lack of promotion of education among them. Although Islam was always barely perceptible in the wider public, Muslims were liable to lose their jobs. ${ }^{33}$ The long-term period of intimidation began to target Pomak communities since the 1970s, the majority of whom was subjected to physical and psychological terror tactics aimed at forcing them to 'adopt back' Bulgarian identity. ${ }^{34}$ Many refused and were therefore imprisoned. The de-Stalinisation of Eastern Europe and the rehabilitation of Stalin's victims did not have much importance in Bulgaria, ${ }^{35}$ where 1300 citizens, 500 of whom were Pomaks, were tortured and sent to prison on Belene Island. ${ }^{36}$

As the time passed by, at the moment of the upcoming advent of Gorbachev, in the highest echelons of the Communist Party, ethnic Turks and other Bulgarian Muslims were forced to choose from a list of Christian names ${ }^{37}$ or Slavic ones that 'they wished to adopt'. Between 1984 and 1989, the communist regime carried out the largest military operation undertaken by the Bulgarian army since the end of the Second World War ${ }^{38}$ and one of the cruellest policies of 'identity transformation' of Turks in general and Muslims in particular. Under the name of 'Great Revival', Bulgarian Turks and Muslims were given by force Bulgarian names in order to align them with a Slavonic 'ethnic code'. Unveiling a never-ended anti-Turkish mentality in Bulgaria, those ethnic Turks who postponed changing their names, or openly refused to do so, were forced to adopt anyway a different name decided by Bulgarian authorities,

31 Mark et al., 1989, 83-84.

32 Ibid. 174-178.

33 Crampton, A Concise History, 58.

34 Ibid.

35 Ibid.

36 Ibid. 59.

37 Jordan Baev, 'De-Stalinisation and Political Rehabilitations in Bulgaria', in De-Stalinising Eastern Europe. The Rehabilitation of Stalin's Victims after 1953, ed. by Kevin McDermott and Matthew Stibbe (London: Palgrave Macmillan, 2015), 164. 
which had the last word on which name was 'proper' per each person. Especially in 1985, the 'Great Revival' provoked yet another mass-scale migration of 350,000 Bulgarian-Turks (of whom about 100,000 later returned to Bulgaria) in the direction of Turkey. Once again, state confiscations of Muslim properties and charitable foundations reduced the number of functioning mosques and persecution of Muslim leaders. ${ }^{39}$ Halil Ahmedov Ibishev, a Turkish figure who left Bulgaria during the campaign with Naim Süleymanov, was told to explain to his community that anyone who resisted would be "killed like a dog..40 Although Muslims did not have permission to carry weapons in the army, ${ }^{41}$ thus less likely to be inconspicuously in possess of weapons, the communist regime discovered documents about a Cyprus-like Turkish action in Southern Bulgaria which was (arguably) about to break up and supported by pan-Turkic and pro-Turkey nationalism. To a certain extent, this potential threat justified the 'regenerative process' that Muslim Turks had gone through, to whom it was allowed to return to the bosom of their mother nation..$^{42}$ In convincing them to have had once 'Bulgarian roots', thus Bulgarian descendants and family connections with Bulgarian ancestors lost in time due to the mass-scale conversation to Islam that the Ottoman domination imposed ${ }^{43}$ communist Bulgarian authorities managed to damage their reputation in the wider Muslim world. What had become a de facto dogmatic position for all Bulgarian academia, was the ideological cornerstone of the 'Revival Process', whose implementation and consequences failed to register in scholarship of European public memory after 1989. ${ }^{44}$

In the course of the fall of the Communism and the arrival of democracy, common hostility and mistrust toward ethno-minority groups did not disappear in Bulgaria. While on a political level the newly established Bulgarian Union of Democratic Forces (UDF), the main platform of anti-communist organisations and voices, did not show much willingness to break convincingly with the nationalist legacy of the communist past, ${ }^{45}$ on a cultural level Bulgaria had to seriously restore its national identity. Throughout, ethnic Turks and Muslims embraced a certain kind of oriental legacy ${ }^{46}$ that in the eyes of Bulgarians meant 'backwardness'. In support of a European identity, the whole Bulgarian political spectrum was founded on an explicit rejection of the country's errant oriental qualities. The Bulgarian Socialist Party (BSP), the main heir of the political culture of the previous Communist regime, came to

39 Merdjanova, 'Uneasy Tolerance'.

40 Crampton, A Concise History, 60.

41 Ibid. 58.

42 Baev, 'De-Stalinisation'.

43 Mario Marinov, Religious Communities in Bulgaria (Blagoevgrad: South-West University Publishing House, 2017), 74.

44. Tomasz Kamusella, Ethnic Cleansing During the Cold War. The Forgotten 1989 Expulsion of Turks from Communist Bulgaria (New York: Routledge, 2019) 24-25, 67.

45 James Dawson, Cultures of Democracy in Serbia and Bulgaria. How ideas Shape Publics (London: Routledge, 2016).

46 BE De Dominicis, 'The Bulgarian Ethnic Model: Post-1989 Bulgarian Ethnic Conflict Resolution', Nationalities Papers 39, no 3 (2011), 450. 
mobilise Bulgarians against the restoration of cultural rights to the Turkish minority. Ivan Kostov, economic expert for the Union of Democratic Forces (UDF), similarly remarked that '[Bulgarians] have to say what we do not want to be, what [they] want to leave out of Europe... stressing the need »to leave a part of our morality, a part of our oriental nature ${ }^{4}{ }^{47}$

Despite this, ethnic minority groups managed to seek out recognition in 1991 and secured their political representation by establishing the Turkish-nominated Movement for Rights and Freedoms (MRF), which succeeded to uphold basic cultural rights for Bulgaria's ethnic Turks. However, such recognition did not occur through a full recognition of 'ethnic basis' since the legal statement was adopted in accordance with the court decision that denied the MRF to choose its first name, namely 'Movement for Rights and Freedoms of the Turks and Muslims in Bulgaria'. The immediate pressure from the Council of Europe on the Bulgarian Constitutional Court allowed MRF to participate in elections to the Constitutional Assembly of June 10,1990 , despite the fact that the original name was changed and a historical trajectory of suspicion and hostility continued to deter political expression of minority groups in Bulgaria. The MFR has never been recognised on ethnic or religious affiliations forbidden constitutionally by Article 11 (Paragraph 4) which, along with Article 34, obliges all Bulgarian citizens regardless of their ethnicity and religion to learn the official language. In other words, the constitutional clause necessitates the MFR to refuse any position of an ethnic organisation, and, more broadly, dictates the party to accept Bulgaria's majority rights ${ }^{48}$ on a cultural and political level.

Immediately after the communist dissolution, newly established Bulgarian institutions began to deal with the accession process to the European Union. In the eyes of Bulgarians, the opportunity to become an EU member state meant nothing but keeping the 'right track' against the one that had mistakenly led astray Bulgaria under the so-called Turkish yoke ${ }^{49}$ firstly, and the Moscow-centred communist power secondly. Against the pitfall to be associated with backwardness as happens for the Balkans, ${ }^{50}$ in the attempt to secure its accession to EU, Bulgaria ratified the Framework for the Protection of National Minorities in 1999 and reintegrated a minor component of Turkish-language provision in some of the country's schools ${ }^{51}$ after having been suspended in 1975. On the other hand, however, the constant and never-ending hostility toward Islam in general and Muslims in particular conformed beyond any doubt the psychological revenge of the Bulgarian ethnos against historical pages of domination and suffering in the 'Ottoman waiting room'. Among others, this may explain why the post-accession period did not mean only stagnation for Bulgaria

47 Dawson, Cultures of Democracy, 88.

48 De Dominicis, 'The Bulgarian Ethnic Model', 84.

49 Crampton, A Concise History, 160.

50 Snyder and Younger, The Balkans, 1.

51 De Dominicis, 'The Bulgarian Ethnic Model', 88. 
as EU Member State, but also a noticeable backsliding ${ }^{52}$ with regard the respect of minority rights in the country.

Three decades since the dissolution of the Eastern Bloc, Bulgaria's de facto minority party, namely the MRF, represents an 'enigma-within-an-enigma.53 While it seems to be culturally paramount for Bulgarian elites to offer an anti-Turkish rhetoric in order not to be seen in political cohabitation with the MRF, the latter has taken part in majority coalition in the Parliament in the last years, and, together with BSP and GERB respectively, it has kept close and unhealthy relations with economic elites. ${ }^{54}$ Often, however, the majority of political parties accuse the MRF to stock ethnic tensions, ${ }^{55}$ and the latest decision of the Local Council of Stara Zagora to 'Bulgarise' place-names with a clearly Turkish or Arabic origin, confirmed that behind the ratification of international conventions, the mentality of most Bulgarians has not changed much. There is little doubt, however, that post-Communist Bulgaria's national identity lies in a sort of ideological continuum that the Bulgarian authorities and their master narrative have historically held and performed against the heirs of Ottoman representatives after 1878. Since the liberation of Bulgarian from the so-called "Turkish yoke", a widespread anti-Turkish sentiment largely marked ideologically the country power institutions and Bulgarians. At present, common knowledge and values of national identity reflect a constant image of ethnolinguistic-ethnoreligious nationalism steeping in the Bulgarian language and Orthodox Christianity. The latter is, in the very end, the troubling continuity of a de-facto colonialization that has never stopped to function from Communism to the first demonstration for democracy in Bulgaria, where those who called for the return of the names of Turks and Muslims, were accused of being "traitors" and "enemies of the Bulgarian nation".56

\section{Conclusion}

In the contemporary history of Bulgaria, the study-case of minority groups reveals how power-organised methods of factual colonialisation in public policies were simply implemented on the ground by looting natural resources and (dis-)possessing cultural legacies of certain segments of society. In other words, hierarchic relationships between Ottoman Turks and subaltern Bulgarians were reorganised after the 1878 Bulgarian liberation movement against the subaltern Turks. The latter can be usually reserved for discussions in a global history context - namely, colonialism and anti-

52 Domaradzki, 'Opportunistic Legitimisation', 230.

53 Clive Leviev-Sawyer, Bulgaria: Politics and Protests in the 21st Century (Sofia: Riva, 2015).

54 KH Pedersen and L Johannsen, 'Democratic Consolidation: A Matter of Shared Values. The Case of Bulgaria', in Twenty Years Since the Fall of the Berlin Wall: Transitions, State Break-Up and Democratic Politics in Central Europe and Germany, ed. by E Bakke and I Peters (Berlin: DWB, 2011), 89.

55 Dawson, Cultures of Democracy, 163.

56 Kamusella, Ethnic Cleansing During the Cold War, 73. 
colonialism. ${ }^{57}$ Relatedly, hierarchic relationships in the liberated Bulgaria and Turkish/ Muslim communities have to be systematically understood through the role of ethnonationalist parties ${ }^{58}$ since minority communities themselves began to be culturally targeted and politically discarded in their daring attempts to raise their heads against brutal exploitation and enormous poverty. ${ }^{59}$ In fact, the 'Great Revival' was only the darkest chapter of a cultural patronisation that Turkish minority members began to be affected by much earlier. Either imprisoned or forced to migrate ${ }^{60}$ or accused of stoking enmity toward Bulgarians and Bulgaria's statehood, all of these have historically been nothing else than a veiled machinery of colonising Other's being, which is nowadays salient in the hostile sentiment against Muslims, Roma and Turks, ${ }^{61}$ upon whom an anti-Islam discourse is continuing to be discursively ascribed in order to fuel the wider public and point out the 'demonic' essence of such religious belief system and peoplehood. In this regard, despite the fact that Bulgaria's Muslim or Turkish communities have never played a critical role throughout the Bulgarian society, it seems obvious that the transnational essence of Islam emphasises how the issue of Bulgarian Muslims is no longer different from those present in Western Europe, which, for a matter of fact, are post-colonial nations. Epistemologically, there is no much distinction between how the communist regime presented the Great Revival, namely as 'a completely safe process' that occurred 'speedily, spontaneously, and calmly' as result of 'a historical maturity', ${ }^{\prime 2}$ and how Boyko Borrisov openly declared in 2008 that the same Great Revival 'had the right aims, but was implemented badly.63 To a certain extent, today's political rhetoric in Bulgaria wins the ground under slogans of 'Roma Crime' as well as 'No More Gypsyness', looking upon the Turkish-dominated MFR party as the main agent malignantly devoted to increase disloyal attitudes toward Bulgaria.

In Bulgaria, however, a 'minority perspective' sheds light on how violence and power-oriented mechanism of cultural patronisation across different locally-nuanced areas have been carried out similarly to other (semi-)colonial countries. The latter took place through (a) dispossession of land, which brings, above all, dignity, ${ }^{64}$ (b) the instrumentally created dependence on ethnicist institutions that impose a sociocultural direction in social life, and a type of (c) oppression that does not clearly

57 Snyder and Younger, The Balkans, 2.

58 Frantz Fanon, The Wretched of the Earth, trans. by Constance Farrington (London: Penguin Books, 2011), 37-47.

59 Noam Chomsky, The New Military Humanism. Lessons from Kosovo (London: Pluto Press, 1999), 50.

60 Baev, 'De-Stalinisation', 164.

61 Sonya Emilova, 'Bulgaria', in European Islamophobia Report 2017, ed. by Enes Bayrakly and Farid Hafez (Istanbul: SETA, 2018), 127.

62 Janice Broun, Conscience and Captivity. Religion in Eastern Europe (Washington, D.C.: Ethics and Public Policy Centre, 1988), 60.

63 Dawson, Cultures of Democracy, 88.

64. Fanon, The Wretched, 34. 
go along ethnic lines but functions through a subtler process of control firstly, and human marginalisation secondly.

Granted so, the post-colonial paradigm is simply a scholarly attempt to disentangle post-socialist trajectory of power that CEE nations are still experiencing while barely masking strife for shaping a realm of coexistence. Underneath, the colonially imposing identity-manoeuvring and behaviour-forming process upon certain segments of peoples ${ }^{65}$ veil a much subtler category of thinking (people's mentality) that has been left at work in the region. Although 'communist colonialism' formally ceased to exist in CEE since 1989, hierarchic methods of doing politics have been embedded into a certain political thinking and cultural knowing that have historically emerged within already-made externally constructed boundaries based on interests of hegemons. ${ }^{66}$ To put it simply, the post-colonial paradigm in CEE in general, and Bulgaria in particular, discovers how certain minority groups have gone through a process of 'colonialisation of being', of their collective identities, on a cultural level. It is not a manifesto-like 'liberation struggle' that on a political level was visible in Global South. It is, once again, a power-organised machinery of cultural patronisation that has come throughout changes of power structures to be simply reversed against those who had used it before against the ones who now possess it. Therefore, if applied over minority groups, post-colonial paradigm is nothing but a vector to discover a way of thinking shaping a sense of 'inferiority' upon a certain segment of the society, where, paradoxically, those who are affected by, tend to interiorise such an externally imposed mechanism of othering.

To conclude, while a 'communist Bulgarian colonialism' has never existed, the post-colonial paradigm shows how certain forms of living and knowing in relation to 'ethnic', 'gender', 'radical', and, to a certain extent, 'political' features of minority groups have been colonised. What the 'former' Bulgarians as minority suffered from Ottoman and Communist rules - namely, being colonised by an overwhelming ideology of kumshu firstly and socialism secondly, began to be suffered by those minorities in the post-Ottoman and post-Communist period. This form of colonisation may be understood as a mechanism of politics to discard human conditions of certain nonaligned groups in society, whose marginalisation and exclusion cannot exclusively represent political issues, but, above all, systematical policies that set apart and suppress different lifestyles, religious systems, process of knowing and so forth.

65 Ágnes Daróczi, 'Shouldn't We Have a History?' in Populism, Memory, and Minority Rights. Central and Eastern European Issues in Global Perspective, ed. by Anna-Mária Bíró (Leiden: Brill, 2018), 20-35.

66 Castellino, 'Identity and Human Rights', 344. 


\section{References}

Baev, Jordan: 'De-Stalinisation and Political Rehabilitations in Bulgaria', in De-Stalinising Eastern Europe. The Rehabilitation of Stalin's Victims after 1953, ed. by Kevin McDermott - Matthew Stibbe. London: Palgrave Macmillan, 2015. 150-169. DOI: 10.1057/9781137368928_8

Braueunlein, Peter J: 'Postcolonial Theory', in Religion and Southeast Asia: An Encyclopaedia of Faiths and Cultures, ed. by Jesudas Athyal. Santa Barbara: ABC-CLIO, 2014. 1-8.

Broun, Janice: Conscience and Captivity. Religion in Eastern Europe. Washington, D.C.: Ethics and Public Policy Centre, 1988.

Brown, JF: Bulgaria under Communist Rule. London: Pall Mall Press, 1970.

Castellino, Joshua: 'Identity and Human Rights in a "Populist" Era: Urging Caution and Pragmatism in Minority Rights Protection', in Populism, Memory, and Minority Rights. Central and Eastern European Issues in Global Perspective, ed. by Anna-Mária Bíró. Leiden: Brill, 2018. 342356. DOI: 10.1163/9789004386426_015

Chomsky, Noam: The New Military Humanism. Lessons from Kosovo. London: Pluto Press, 1999.

Crampton, Julian R: A Concise History of Bulgaria. Cambridge: Cambridge University Press, 2005. DOI: $10.1017 /$ cbo9780511996870

Daróczi, Ágnes: 'Shouldn't We Have a History?' in Populism, Memory, and Minority Rights. Central and Eastern European Issues in Global Perspective, ed. by Anna-Mária Bíró. Leiden: Brill, 2018. 20-35. DOI: 10.1163/9789004386426_003

Dawson, James: Cultures of Democracy in Serbia and Bulgaria. How ideas Shape Publics. London: Routledge, 2016. DOI: 10.4324/9781315575544

De Dominicis, BE: 'The Bulgarian Ethnic Model: Post-1989 Bulgarian Ethnic Conflict Resolution' Nationalities Papers 39, no 3 (2011), 441-460. DOI: 10.1080/00905992.2011.565317

Domaradzki, Spasimir: 'Opportunistic Legitimisation and de-Europeanisation as a Reverse Effect of Europeanisation'. Global Discourse. An Interdisciplinary Journal of Current Affairs 9, no 1 (2019), 221-244. DOI: 10.1332/204378919x15470487645475

Emilova, Sonya: 'Bulgaria', in European Islamophobia Report 2017, ed. by Enes Bayrakly and Farid Hafez. Istanbul: SETA, 2018. 127-142.

Fanon, Frantz: The Wretched of the Earth, trans. by Constance Farrington. London: Penguin Books, 2011.

Fejtö, François: A History of the People's Democracies. Eastern Europe Since Stalin. Middlesex: Penguin Books, 1974.

Foucault, Michel: Nietzsche, Genealogy and History. Oxford: Blackwell, 1971.

Foucault, Michel: The Archaeology of Knowledge. New York: Routledge Classics, 2002.

Hirsh, Marianne: The Generation of Postmemory. Writing and Visual Culture After the Holocaust. New York: Columbia University Press, 2012.

Kamussela, Tomasz: Ethnic Cleansing during the Cold War. The Forgotten 1989 Expulsion of Turks from Communist Bulgaria. New York: Routledge, 2019. DOI: 10.4324/9781351062701

Kołodziejczyk, Dorota: 'Post-Colonial Transfer to Central-and-Eastern Europe'. Teksty Drugie no 1 (2014) (Special Issue), 124-142.

Kushnir, Ostap: Ukraine and Russian Neo-Imperialism. The Divergent Break. Lanham: Lexington Books, 2018, 25-65.

Leviev-Sawyer, Clive: Bulgaria: Politics and Protests in the 21st Century. Sofia: Riva, 2015.

Marinov, Mario: Religious Communities in Bulgaria. Blagoevgrad: South-West University Publishing House, 2017. 
Mark, James et al.: 1989. A Global History of Eastern Europe. Cambridge: Cambridge University Press, 2019.

Merdjanova, Ina: 'Uneasy Tolerance: Interreligious Relations in Bulgaria after the Fall of Communism'. Occasional Papers on Religion in Eastern Europe 26, no 1 (2006), 1-11.

Pedersen, KH and L Johannsen: 'Democratic Consolidation: A Matter of Shared Values. The Case of Bulgaria', in Twenty Years Since the Fall of the Berlin Wall: Transitions, State Break-Up and Democratic Politics in Central Europe and Germany, ed. by E Bakke and I Peters. Berlin: DWB, 2011, 77-96.

Rexhepi, Piro: 'Unmapping Islam in Eastern Europe: Periodization and Muslim Subjectivities in the Balkans', in Eastern Europe Unmapped: Beyond Borders and Peripheries, ed. by I Kacandes and Y Komska. New York: Berghahn, 2018, 53-78. DOI: 10.2307/j.ctvw049zd.7

Shenk, Gerald: 'What Went Right: Two Best Cases of Islam in Europe - Cordoba, Spain and Sarajevo, Bosnia'. Occasional Papers on Religion in Eastern Europe 26, no 4 (2006), 7-20.

Snyder, Timothy and Katherine Younger (eds.): The Balkans as Europe, 1821-1914. Rochester: University of Rochester Press, 2018. DOI: 10.1017/9781787442290

Terian, Andrei: 'Is there an East-Central European Post-Colonialism? Towards a Unified Theory of (Inter)Literacy Dependency'. World Literature Studies 3, no 4 (2012), 21-36.

Tlostanova, Madina: 'Towards a Decolonization of Thinking and Knowledge: a Few Reflections from the World of Imperial Difference.' Decolonial Theory and Practice in Southeast Europe no 3 (2019) (Special Issue), 1-15. 